\title{
INDIVIDUAL FUTURE ORIENTATION AND DEMOGRAPHIC FACTORS PREDICTING LIFE SATISFACTION
}

\author{
Aleksandrs Kolesovs \\ University of Latvia, Latvia
}

\begin{abstract}
This study explored a model of prediction of life satisfaction by individual future orientation (FO) and demographic factors. Individual views of the future and goals are closely associated with well-being. Theories of FO represent different approaches to its conceptualization. Following Seginer (2009), this study presents a combination of motivational, cognitive, and behavioral components of FO. Participants were 130 females and 75 males from 18 to 49. A new measure of individual FO (the Individual Future Orientation Scale, IFOS) and the Satisfaction With Life Scale (Diener, Emmons, Larsen, \& Griffin, 1985) were used for the assessment. The results of structural equation modeling demonstrate that relatively higher life satisfaction is predicted by higher individual FO and higher income assessed as an income range and subjective satisfaction with it. Therefore, subjective involvement in a pursuit of future goals and financial background add to understanding of individual satisfaction with life.
\end{abstract}

Keywords: demographic factors, future orientation, life satisfaction.

\section{Introduction}

Satisfaction with life is a substantial component of subjective well-being (Diener, 1984; Diener, Emmons, Larsen, \& Griffin, 1985; Diener, Suh, Lucas, \& Smith, 1999). Associated with happiness, this approach to well-being is not reducible to physical hedonism and involves generalized satisfaction with one's goals and progress in their attainment (Diener et al., 1999; Ryan \& Deci, 2001). Empirical studies confirm the association between goal pursuit and life satisfaction (Krings, Bangerter, Gomez, \& Grob, 2008; Salmela-Aro, Pennanen, \& Nurmi, 2001). In addition, life satisfaction is impacted by demographic factors and SES, personality traits and cognitive dispositions (Diener et al., 1999), sociohistorical context and social support (Krings et al., 2008). The aim of this study was the further exploration of predicting life satisfaction by individual future orientation and demographic factors. 


\section{Predictors of life satisfaction}

Multiple determination of life satisfaction results in a variety of findings on key determinants (see Diener et al., 1999 for a review). Among demographic variables, higher income, education, marriage, and religiosity explain higher satisfaction with life. At the same time, a comparison of Eastern and Western countries (Ngoo, Tey, \& Tan, 2015) demonstrated that some factors (e.g., marriage) can have higher impact on life satisfaction, while other factors (e.g., education) can lose their significance in Eastern countries. In Latvia, Upmane (2010) confirmed significance of higher income, education, relationships' status, and religiosity in understanding of life satisfaction. Among subjective variables, higher satisfaction with personal development, interpersonal relationships, financial situation and income, higher positive affect, and lower negative affect were the predictors of higher life satisfaction (Upmane, 2010).

Inconsistency of findings is higher in the field of individual goals. Despite of an association between goal pursuit and life satisfaction (Krings et al., 2008; Salmela-Aro et al., 2001), some studies do not confirm the relationship between future orientation and perceived happiness (Zimbardo \& Boyd, 1999; Drake, Duncan, Sutherland, Abernethy, \& Henry, 2008). Observed differences can be explained by different conceptualization of individual orientation towards goals, which is also designated as individual future orientation (see Seginer, 2009 for a review). The most generalized view (Zimbardo \& Boyd, 1999; Drake et al., 2008) represents individual orientation towards future goals as a single dimension. Important aspects of the process of goal pursuit and its evaluation can be lost by taking this generalized perspective. More specific view of individual future orientation (Seginer, Vermulst, \& Shoyer, 2004) involves a set of individual goals (cognitive component), value of goals, control over their attainment, and goalrelated expectations (motivational component), and exploration of and commitment to goals (behavioral component). These specific aspects of future orientation associate with higher life satisfaction (Diener et al., 1999; Krings et al., 2008; Salmela-Aro et al., 2001). At the same time, the question about the relationship between more generalized future orientation and life satisfaction remains.

In order to explore the relationship, the present study suggests a new approach to individual future orientation. It compromises two well-known models: a general orientation towards the future (e.g., Zimbardo \& Boyd, 1999) and a combination of specific aspects of orientation towards goals in a particular domain (Seginer et al., 2004). Within the frame of the current study, individual future orientation was considered as a latent factor (generalization) of motivational, cognitive, and behavioral components of individual orientation towards one's goals. This kind of generalization can be considered as goal-based 
in comparison with the model of Zimbardo and Boyd (1999). The latter represents some aspects of personality characteristics (e.g., consideration of future consequences) appearing in its factorial structure (Kolesovs, 2009).

It was hypothesized that the generalization of goal-oriented aspects of individual future orientation will be among predictors of life satisfaction. In order to control an effect of evaluation of the future associated with goal-oriented FO (e.g., Nuttin \& Lens, 1985), it was added to the list of predictors. Taking into account findings of Krings et al. (2008), perceived social support was also included into the model.

\section{Method}

Participants. Research participants were 130 females and 75 males from 18 to 49 (mean age was 23.97, $\mathrm{SD}=5.50$ ). The most part of them (about $89 \%$ ) were university students. Some level of higher education was acquired by $33 \%$ of participants. About $11 \%$ of participants were married. There was $51 \%$ of working participants. The income level of $71 \%$ of participants was no lower than the mean income per person in the household in Latvia (Central Statistical Bureau of Latvia, 2014).

Measures. The Individual Future Orientation Scale (IFOS) was developed for the assessment of general future orientation based on its motivational, cognitive, and behavioral aspects emphasized by Seginer et al. (2004). The scale contains eight groups of questions (see Appendix) associating with near and distal individual goals and forming three subscales. A seven-point Likert-type scale was provided for answers. Summary scores of subscales and of the scale were calculated by dividing the sum of specific items by the number of items. The scale was developed and applied in Latvian.

Motivational subscale involves questions regarding perceived control over goals, expectancy of their fulfillment, and perceived value of goals (Questions 6, 7 , and 8 , respectively). Each aspect of motivation was assessed in regard to near and distal goals. For example, the question "How important are these goals for you?" represented perceived value of goals and was answered in regard to near goals and distal goals (two items).

Cognitive subscale was developed on a basis of a previous study (Kolesovs, 2015) and evaluated the content of future goals by answering two questions (Questions 2 and 3): "To what extent your near [next question - distal] goals are associated with the following domains?" Nine specific domains were assessed after each question: education, occupation and career, family and marriage, children, friends, parents and relatives, leisure, property and money, and personal growth. Added items are in italics. 
It should be noted that there is no conflict between the use of items for assessment of a generalized tendency and the use of the same items for the assessment of separate domains in the previous study (Kolesovs, 2015). Different uses are dependent on the goal of the study. Exploration of generalized future orientation requires focusing on a common component in assessment of different goals. Common variance of different domains was also analyzed in a study on goals' variability within and between individuals (Nurmi, Salmela-Aro, \& Aunola, 2009).

Behavioral subscale assesses individual commitment to goals and exploration of opportunities for their fulfillment. These aspects are evaluated by three questions regarding definitiveness of goals (Question 1), efforts in their specification (Question 4), and exploration of opportunities for their fulfillment (Question 5). Similarly to motivational scale, behavioral aspects were assessed in regard to both near and distal goals. For example, the question "Do you have defined your personal goals?" represented commitment to goals and was answered in regard to near goals and distal goals separately.

The Satisfaction With Life Scale (Diener et al., 1985) was used for the assessment of life satisfaction. The scale consists of five items assessed on a seven-point Likert-type scale. An item example: "In most ways my life is close to my ideal." One of Latvian versions of the scale was applied (Upmane, 2010). Cronbach's alpha coefficient was .83.

Two additional measures were used. First, perceived support at a mesosystem level was assessed by a measure suggested by Kolesovs (2015). It was assessed as support for goal attainment provided by parents, siblings, relatives, and friends by asking "To what extent your goals are supported by people listed below?" (Appendix, Question 9). Cronbach's alpha coefficient for the subscale was .70. Second, evaluation of the future was assessed by asking "Please evaluate each temporal interval of your life." Three intervals were assessed (Appendix, Question 10), but evaluation of the future was calculated by summing evaluation of the near and distal future. Cronbach's alpha for this measure was .60 (slightly lowered).

Procedure. The questionnaire in a paper-and-pencil format was filled in without time limit individually or in groups. In addition, 34 participants completed the IFOS over a four-week interval in order to assess test-retest reliability of the scale.

\section{Results}

At the first step, two main aspects of reliability of the IFOS were assessed. Table 1 presents internal consistency and test-retest reliability of the IFOS. 
Table 1 Reliability of the IFOS and its subscales $(\boldsymbol{N}=\mathbf{2 0 5})$

\begin{tabular}{|c|c|c|c|}
\hline Scale & Items & $\begin{array}{c}\text { Cronbach's alpha } \\
\text { coefficient }\end{array}$ & $\begin{array}{c}\text { Test-retest reliability, } \\
\text { 4 weeks }(\boldsymbol{n}=\mathbf{3 4})\end{array}$ \\
\hline Future Orientation & 30 & .86 & .81 \\
\hline Motivational & 6 & .70 & .73 \\
\hline Cognitive & 18 & .83 & .85 \\
\hline Behavioral & 6 & .81 & .72 \\
\hline
\end{tabular}

The second step involved suggested measures into a correlational analysis. Table 2 reflects the results of the analysis. It was found that age, gender, employment, and having children do not correlate with life satisfaction. Significant correlations were found for individual future orientation, evaluation of the future, perceived social support, perceived income, higher income range, having higher education, and marriage.

Table 2 Correlates of life satisfaction $(\boldsymbol{N}=\mathbf{2 0 5})$

\begin{tabular}{|l|l|}
\hline Variables & Life Satisfaction \\
\hline Age & .11 \\
\hline Gender (female) & .10 \\
\hline Employment & .08 \\
\hline Higher Education & $.15^{*}$ \\
\hline Marital status (married) & $.17^{*}$ \\
\hline Children & .12 \\
\hline Higher Income (over the mean) & $.34^{* * *}$ \\
\hline Perceived Income & $.28^{* * *}$ \\
\hline Perceived Social Support & $.24^{* *}$ \\
\hline Evaluation of the Personal Future & $.40^{* * *}$ \\
\hline Individual Future Orientation (IFOS sum) & $.41^{* * *}$ \\
\hline
\end{tabular}

$* p<.01 ; * * p<.01 ; * * * p<.001$.

At the third step, a structural equation model was applied in order to assess predictors of life satisfaction and their covariation. The measurement model involved three components of individual future orientation. Therefore, individual future orientation was represented as a latent variable. Five of six significant correlates were added to the model as exogenous variables or predictors of life satisfaction. Marital status was excluded from the analysis because of underrepresentation of married individuals (11\% only).

Figure 1 presents the model, significant coefficients, and covariations among predictors. Statistical package 'lavaan' (0.5-22) for R (Rosseel, 2012) was used for the assessment of the model. Satorra-Bentler correction was applied in the assessment of the robust model fit through maximum likelihood method. Scaling 
correction factor was 1.15 . The model demonstrated no significant deviance from data and acceptable fit indexes: $\chi^{2}(12)=12.40, p=.414, \mathrm{CFI}=0.99$, TLI $=0.99$, $\mathrm{RMSEA}=.01(90 \%$ confidence interval from .00 to $.07, p=.806)$, SRMR $=.03$.

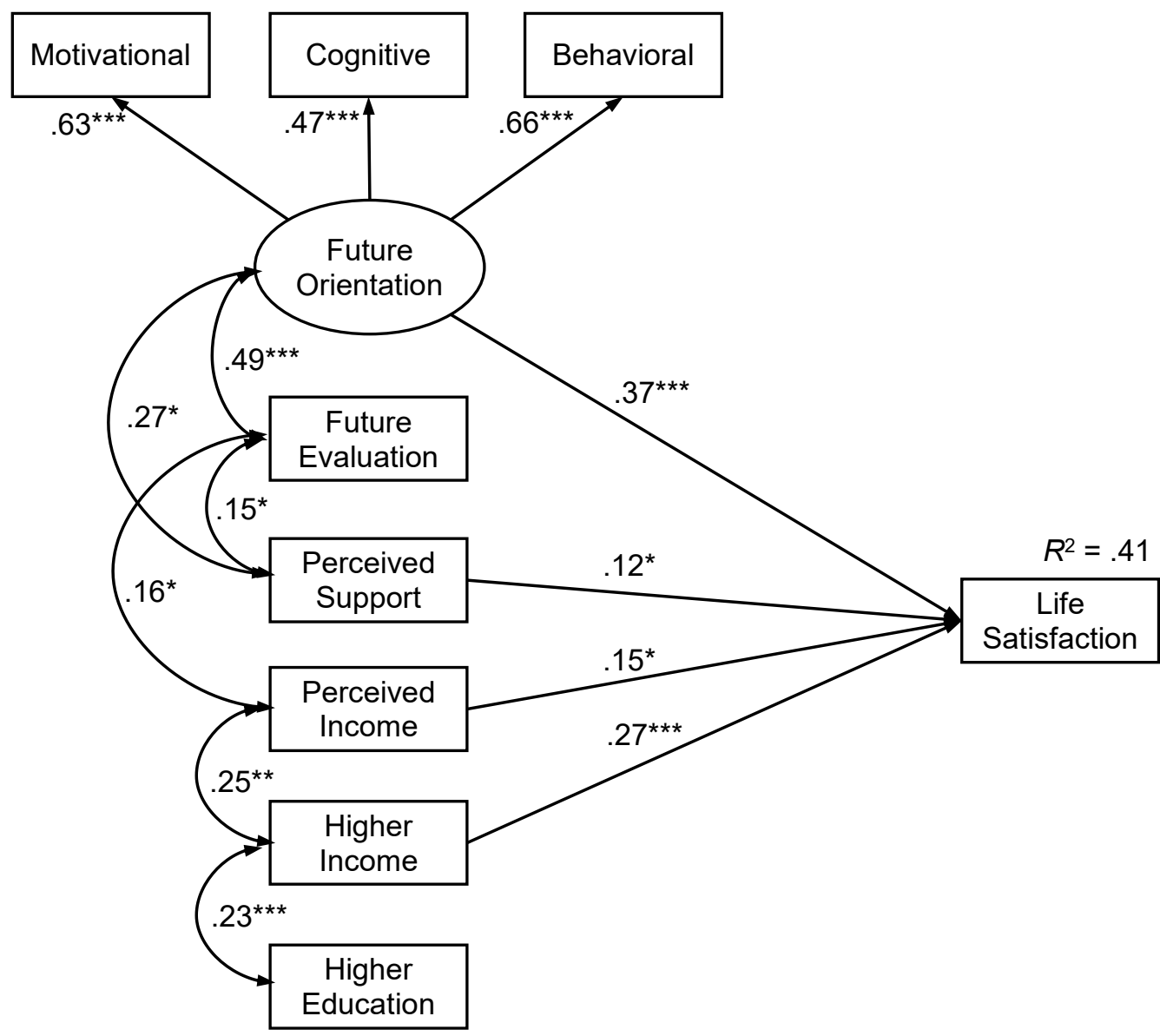

Figure 1 Standardized regression coefficients and covariation among predictors of life satisfaction

Model invariance was assessed for gender by statistical package 'semTools' for $\mathrm{R}$ based on suggestions of Vandenberg and Lance (2000). The results indicated invariance of the model for factorial loadings, $\Delta \chi^{2}(2)=0.49, p=.781$, intercepts, $\Delta \chi^{2}(3)=2.64, p=.450$, and means, $\Delta \chi^{2}(1)=0.56, p=.453$.

\section{Discussion}

In general, the results confirm multiple determination of life satisfaction. The most powerful predictors are higher individual FO and higher income level reported by participants. Therefore, the hypothesis regarding individual FO is confirmed. In addition to objective income data, higher subjective satisfaction 
with the level of income adds to higher life satisfaction. Perceived support is the fourth predictor revealed in the study.

Among demographic predictors, higher income level is in accordance with previous findings (Diener et al., 1999; Ngoo et al., 2015; Upmane, 2010). Higher education demonstrated low level of correlation with life satisfaction and is not among its predictors. It can be explained by relatively low variation of the level of education in the current study. The most part of the participants were university students. Therefore, other developmental trajectories are underrepresented and should be included into the further research.

Significant prediction of life satisfaction by FO is a step in understanding observed lack of correlation between FO and perceived happiness (Zimbardo \& Boyd, 1999; Drake et al., 2008). The new model of FO generalizes individual motivation, cognitive representations, and goal-relevant behavior as important aspects of goal pursuit presented by Seginer et al. (2004). Therefore, individual FO as a generalized view of goal pursuit demonstrates significant association with life satisfaction considered in previous studies (Diener et al., 1999; Krings, et al., 2008; Ryan \& Deci, 2001; Salmela-Aro et al., 2001), while FO as a personality characteristic is less associated with it (Zimbardo \& Boyd, 1999; Drake et al., 2008).

The new model of FO seems provide a successful compromise between a detailed exploration of domain-specific goals (Seginer et al., 2004; Nurmi et al., 2009) and individual future orientation as an element of individual time perspective (Zimbardo \& Boyd, 1999). At the same time, relatively low factorial load of cognitive component is in accordance with a conclusion on relatively low common variance of individual goals in different domains (Nurmi et al., 2009). Therefore, the IFOS cannot substitute instruments for detailed exploration of domain-specific goals (e.g., Seginer et al., 2004), but is useful in the case of a generalized representation of FO. Revealed association of FO with evaluation of the future demonstrates that the IFOS can be extended for representing a broader view of future orientation (e.g., Nuttin \& Lens, 1985).

It should be noted that the current study has important limitations. Development of a new model of individual FO limited including individual views of the past and the present as significant background for predicting life satisfaction (Diener et al., 1985; Drake et al., 2008). As a result, explained variance of life satisfaction is about $41 \%$. In addition, personality traits and cognitive dispositions (Diener et al., 1999) can be added to the predictive model in the further study. Higher variability of participants can be useful for more correct assessment of predictive demographic factors (marriage, having children, and a level of education).

It can be concluded that subjective and objective factors interact in their prediction of individual life satisfaction. This interaction is the most visible is in 
the domain of income and satisfaction with it. A new representation of individual future orientation as a goal-based construct confirms association of goal pursuit and life satisfaction.

\section{References}

Central Statistical Bureau of Latvia (2014). Income and living conditions in Latvia, 2013. Collection of statistical data (14). Rīga: CSB of Latvia. Retrieved from http://www.csb.gov.lv/sites/default/files/nr_14_ienakumi_un_dzives_apstakli_latvija_2 013_14_00_lv_en.pdf

Diener, E. (1984). Subjective well-being. Psychological Bulletin, 95, 542-575.

Diener, E., Emmons, R. A., Larsen, R. J., \& Griffin, S. (1985). The satisfaction with life scale. Journal of Personality Assessment, 49, 71-75.

Diener, E., Suh, E. M., Lucas, R. E., \& Smith, H. L. (1999). Subjective well-being: Three decades of progress. Psychological Bulletin, 125, 276-302.

Drake, L., Duncan, E., Sutherland, F., Abernethy, C., \& Henry, C. (2008). Time perspective and correlates of wellbeing. Time \& Society, 17, 47-61.

Kolesovs, A. (2009). Factorial validity of the Latvian and Russian versions of the Zimbardo Time Perspective Inventory in Latvia. Baltic Journal of Psychology, 10, 55-64.

Kolesovs, A. (2015). Prediction of distant educational goals by goals in other domains and perceived contextual opportunities. In V. Lubkina, \& S. Usca (Eds.), Society, Integration, Education: Vol. 4. Proceedings of the International Scientific Conference (pp. 40-47). Rēzekne: Rēzeknes Augstskola.

Krings, F., Bangerter, A., Gomez, V., \& Grob, A. (2008). Cohort differences in personal goals and life satisfaction in young adulthood: Evidence for historical shifts in developmental tasks. Journal of Adult Development, 15, 93-105.

Ngoo, Tey, \& Tan (2015). Determinants of life satisfaction in Asia. Social Indicators Research, $124,141-156$.

Nurmi, J.-E., Salmela-Aro, K., \& Aunola, K. (2009). Personal goal appraisals vary across both individuals and goal contents. Personality and Individual Differences, 47, 498-503.

Nuttin, J., \& Lens, W. (1985). Future time perspective and motivation: Theory and research method. Leuven \& Hillsdale, NJ: Leuven University Press \& Erlbaum.

Rosseel, Y. (2012). lavaan: An R Package for Structural Equation Modeling. Journal of Statistical Software, 48 (2), 1-36. http://www.jstatsoft.org/v48/i02/

Ryan, R. M., \& Deci, E. L. (2001). On happiness and human potentials: A review of research on hedonic and eudaimonic well-being. Annual Review of Psychology, 52, 141-166.

Salmela-Aro, K., Pennanen, R., \& Nurmi, J.-E. (2001). Self-focused goals: What they are, how they function, and how they relate to well-being. In P. Schmuck \& K. M. Sheldon (Eds.), Life goals and well-being: Towards a positive psychology of human striving (pp. 148166). Seattle, Toronto, Bern, Goettingen: Hogrefe.

Seginer, R. (2009). Future orientation: Developmental and ecological perspectives. New York, NY, Springer.

Seginer, R., Vermulst, A., \& Shoyer, S. (2004). The indirect link between perceived parenting and adolescent future orientation: A multiple-step model. International Journal of Behavioral Development, 28, 365-378. 
Upmane, A. (2010). Apmierinātību ar dzīvi prognozējošie faktori: kvantitatīva un kvalitatīva analīze [Factors predicting satisfaction with life: Quantitative and qualitative analysis] (Doctoral Dissertation, University of Latvia, Riga, Latvia).

Vandenberg, R. J., \& Lance, C. E. (2000). A review and synthesis of the measurement invariance literature: Suggestions, practices, and recommendations for organizational research. Organizational Research Methods, 3, 4-70.

Zimbardo, P. G., \& Boyd, J. N. (1999). Putting time in perspective: A valid, reliable individualdifferences metric. Journal of Personality and Social Psychology, 77, 1271-1288.

APPENDIX

The Individual Future Orientation Scale (IFOS)

Instrukcija: Aicinu Jūs piedalīties aptaujā, kura iekḷauj jautājumus par Jūsu priekšstatiem par nākotni. Runa ir par Jūsu viedokli, tāpēc nevar būt "pareizās" vai "nepareizās" atbildes. Atbildot uz jautājumiem, lūdzu, apvelciet piemērotu atbildes variantu.

PERSONİGĀ NĀKOTNE

1. Vai Jūs esat noteikuši savus personīgos mērḳus?

\begin{tabular}{|c|c|c|c|c|c|c|c|}
\hline \multicolumn{7}{|c|}{ Nemaz } & Pilnībā \\
\hline Tuvākie mērksi & 1 & 2 & 3 & 4 & 5 & 6 & 7 \\
\hline Attālinātie mērksi & 1 & 2 & 3 & 4 & 5 & 6 & 7 \\
\hline \multicolumn{8}{|c|}{ 2. Cik lielā mērā Jūsu TUVĀKIE mērkiki ir saistīti ar sekojošām jomām? } \\
\hline & Nav aktuāls & Minimāli & & & & & Maksimāli \\
\hline Izglìtība & 0 & 1 & 2 & 3 & 4 & 5 & 6 \\
\hline Darbs/karjera & 0 & 1 & 2 & 3 & 4 & 5 & 6 \\
\hline G̣imene/laulība & 0 & 1 & 2 & 3 & 4 & 5 & 6 \\
\hline Bērni & 0 & 1 & 2 & 3 & 4 & 5 & 6 \\
\hline Draugi & 0 & 1 & 2 & 3 & 4 & 5 & 6 \\
\hline Vecāki/radi & 0 & 1 & 2 & 3 & 4 & 5 & 6 \\
\hline Atpūta & 0 & 1 & 2 & 3 & 4 & 5 & 6 \\
\hline Īpašums/nauda & 0 & 1 & 2 & 3 & 4 & 5 & 6 \\
\hline Personīga izaugsme & 0 & 1 & 2 & 3 & 4 & 5 & 6 \\
\hline
\end{tabular}

3. Cik lielā mērā Jūsu ATTĀLINĀTIE mērḳi ir saistīti ar sekojošām jomām?

\begin{tabular}{|c|c|c|c|c|c|c|c|}
\hline \multicolumn{5}{|c|}{ Nav aktuāls Minimāli } & & & Maksimāli \\
\hline Izglìtība & 0 & 1 & 2 & 3 & 4 & 5 & 6 \\
\hline Darbs/karjera & 0 & 1 & 2 & 3 & 4 & 5 & 6 \\
\hline G̣imene/laulība & 0 & 1 & 2 & 3 & 4 & 5 & 6 \\
\hline Bērni & 0 & 1 & 2 & 3 & 4 & 5 & 6 \\
\hline Draugi & 0 & 1 & 2 & 3 & 4 & 5 & 6 \\
\hline Vecāki/radi & 0 & 1 & 2 & 3 & 4 & 5 & 6 \\
\hline Atpūta & 0 & 1 & 2 & 3 & 4 & 5 & 6 \\
\hline Īpašums/nauda & 0 & 1 & 2 & 3 & 4 & 5 & 6 \\
\hline Personīga izaugsme & 0 & 1 & 2 & 3 & 4 & 5 & 6 \\
\hline
\end{tabular}


4. Vai Jūs veltāt laiku, lai precizētu savus mērḳus?

\begin{tabular}{llllllll}
\hline & Minimāli & & & & & Maksimāli \\
\hline Tuvākie mērḳi & 1 & 2 & 3 & 4 & 5 & 6 & 7 \\
Attālinātie mērksi & 1 & 2 & 3 & 4 & 5 & 6 & 7 \\
\hline
\end{tabular}

5. Vai Jūs meklējat jaunas iespējas, lai piepildītu savus mērḳus?

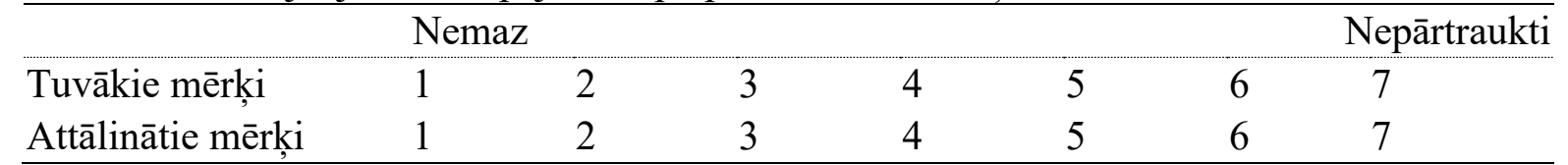

6. Cik lielā mērā Jūsu mērḳu sasniegšana ir atkarīga no Jums?

\begin{tabular}{llllllll}
\hline & Nemaz & & & & & Pilnībā \\
\hline Tuvākie mērḳi & 1 & 2 & 3 & 4 & 5 & 6 & 7 \\
Attālinātie mērksi & 1 & 2 & 3 & 4 & 5 & 6 & 7 \\
\hline
\end{tabular}

7. Cik lielā mērā, Jūsuprāt, Jūsu mērḳi tiks sasniegti?

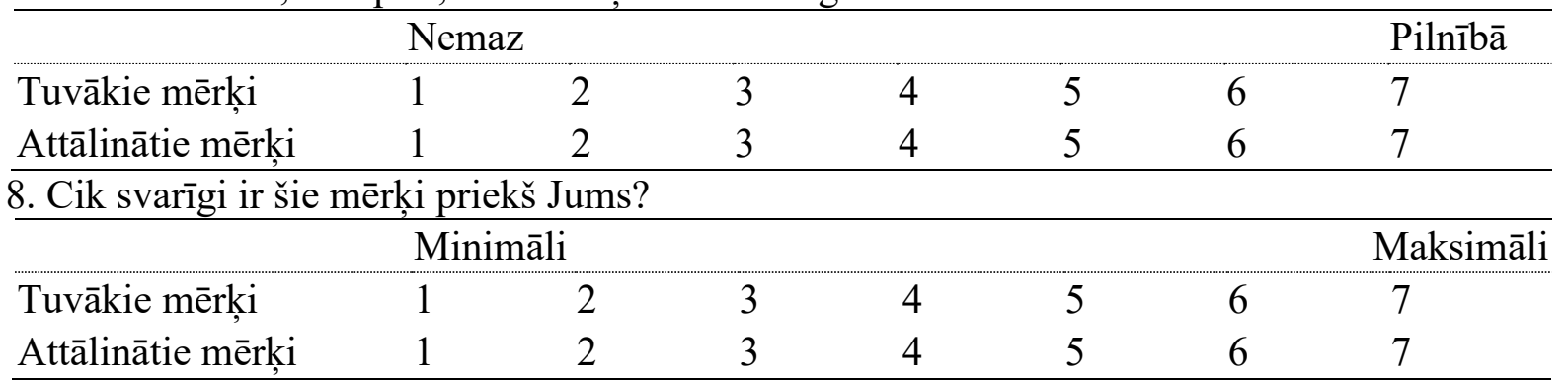

9.* Cik lielā mērā Jūsu mērḳu sasniegšanu atbalsta zemāk norādīitie cilvēki?

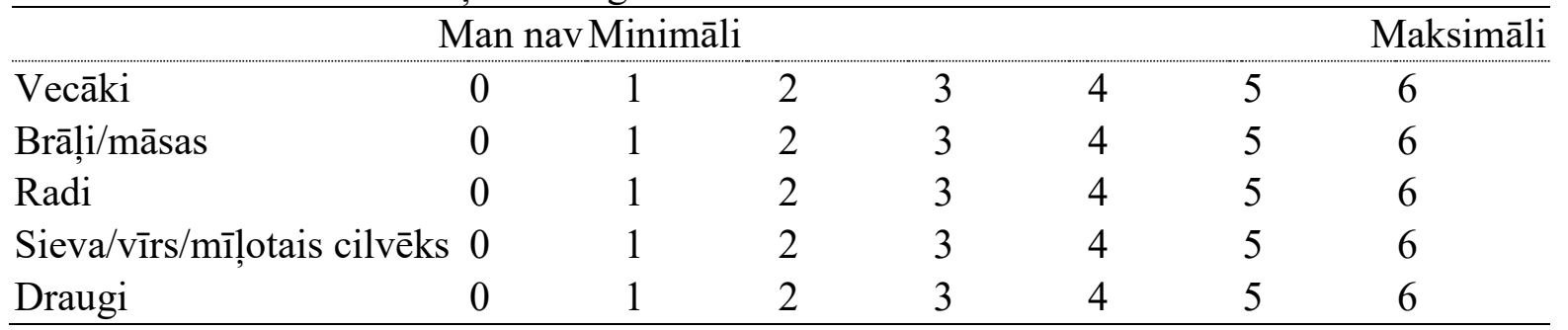

10.* Lūdzu, novērtējiet katru laika intervālu savā dzīvē.

\begin{tabular}{|c|c|c|c|c|c|c|c|}
\hline \multicolumn{4}{|c|}{ Loti negatīva } & & & & Loti pozitīva \\
\hline Tagadne & -3 & -2 & -1 & 0 & +1 & +2 & +3 \\
\hline Tuvākā nākotne & -3 & -2 & -1 & 0 & +1 & +2 & +3 \\
\hline Tāla nākotne & -3 & -2 & -1 & 0 & +1 & +2 & +3 \\
\hline
\end{tabular}

* Question 9 and Question 10 are not a genuine part of the IFOS. 